\title{
Combined ginger extract \& Gelam honey modulate Ras/ERK and PI3K/AKT pathway genes in colon cancer HT29 cells
}

\author{
Analhuda Abdullah Tahir ${ }^{1}$, Nur Fathiah Abdul Sani ${ }^{1}$, Noor Azian Murad ${ }^{2}$, Suzana Makpol', \\ Wan Zurinah Wan Ngah ${ }^{1}$ and Yasmin Anum Mohd Yusof ${ }^{1 *}$
}

\begin{abstract}
Background: The interconnected Ras/ERK and PI3K/AKT pathways play a central role in colorectal tumorigenesis, and they are targets for elucidating mechanisms involved in attempts to induce colon cancer cell death. Both ginger (Zingiber officinale) and honey have been shown to exhibit anti-tumor and anti-inflammation properties against many types of cancer, including colorectal cancer. However, there are currently no reports showing the combined effect of these two dietary compounds in cancer growth inhibition. The aim of this study was to evaluate the synergistic effect of crude ginger extract and Gelam honey in combination as potential cancer chemopreventive agents against the colorectal cancer cell line HT29.

Methods: The cells were divided into 4 groups: the first group represents HT29 cells without treatment, the second and third groups were cells treated singly with either ginger or Gelam honey, respectively, and the last group represents cells treated with ginger and Gelam honey combined.

Results: The results of MTS assay showed that the $I_{50}$ of ginger and Gelam honey alone were $5.2 \mathrm{mg} / \mathrm{ml}$ and $80 \mathrm{mg} / \mathrm{ml}$, respectively, whereas the $I_{50}$ of the combination treatment was $3 \mathrm{mg} / \mathrm{ml}$ of ginger plus $27 \mathrm{mg} / \mathrm{ml}$ of Gelam honey with a combination index of $<1$, suggesting synergism. Cell death in response to the combined ginger and Gelam honey treatment was associated with the stimulation of early apoptosis (upregulation of caspase 9 and $I k B$ genes) accompanied by downregulation of the KRAS, ERK, AKT, BCl-xL, NFKB (p65) genes in a synergistic manner.
\end{abstract}

Conclusions: In conclusion, the combination of ginger and Gelam honey may be an effective chemopreventive and therapeutic strategy for inducing the death of colon cancer cells.

Keywords: Ginger, Gelam honey, HT29 colon cancer cells, Ras/ERK and PI3K/AKT pathways

\section{Background}

Colorectal cancer (CRC) is the third most common cancer and the second leading cause of death among cancers worldwide [1]. Malaysia has also experienced the same increasing trend of colorectal cancer, the second most common cancer in both males and females [2]. Colorectal carcinogenesis is a multistep process that transforms colonic epithelial cells into colon adenocarcinoma cells involving mutation of the $A P C$ gene as an

\footnotetext{
* Correspondence: rahmatyasmin@yahoo.com

'Department of Biochemistry, Faculty of Medicine, Universiti Kebangsaan Malaysia, Jalan Yaacob Latif, Bandar Tun Razak, Cheras, 56000 Kuala Lumpur, Malaysia
}

Full list of author information is available at the end of the article initiator followed by mutations of the genes $K R A S$, PIK3CA, transforming growth factor- $\beta$ and $p 53[3,4]$.

KRAS protein plays a central role in controlling the activity of several crucial downstream signaling pathways such as P13K/AKT/mTOR and Ras/Raf/ERK that regulate normal cellular proliferation, differentiation and survival [5]. Mutations of the KRAS proto-oncogene and any of its downstream elements will lead to abnormal signaling and activation of these pathways, resulting in uncontrolled cell growth [6]. Mutations of the kras proto-oncogene have been found in $30 \%$ to $50 \%$ of early adenoma to intermediate adenoma of colon cancer [6]. Activation of the PI3K/ AKT pathway has also been shown to activate NFKB through phosphorylation of IKK, which in turn 
phosphorylates IkB $\alpha$ and RELA/p65 [7]. The Ras/ERK, PI3K/AKT and NFKB pathways are interconnected and play a central role in colorectal tumorigenesis $[6,7]$. Thus, targeting these crosstalk pathways using combined strong chemopreventive agents may lead to greater inhibition of colorectal carcinogenesis.

Natural dietary phytochemicals have potential to be used in cancer therapy because in addition to reducing adverse side effects, they also improve the effectiveness of chemotherapeutics [8]. These compounds may interfere with carcinogenic processes at various levels, both by blocking initiation and by suppressing the later stages involving promotion, progression, angiogenesis, invasion and metastasis [9]. A growing number of in vitro and in vivo studies have suggested that combinations of dietary phytochemical may be far more effective at protecting against cancer compared to individual compounds [9-12]. Combination treatment with resveratrol and black tea at low dose synergistically inhibits the growth of skin cancer through induction of apoptosis and inhibition of MAPK signaling [10], and the combination of curcumin with garcinol induces apoptosis through increased activity of caspases 3 and 9 in pancreatic cancer cells (BxPC-3 PaCa and PANC-1) [13]. The combination of zingiber officinale and piper retrofractum displays increased apoptosis activity in WiDr myeloma cells [14].

Ginger (Zingiber officinale) contains phenolic compounds such as gingerol, shogaol, paradol, and zerumbone that have been demonstrated to have antioxidant, anti-tumor and anti-inflammatory properties $[15,16]$. Ginger extract and its bioactive compounds were shown to inhibit the growth of oral cancer [16], colon cancer [17], gastric cancer, [18], skin cancer [19], liver cancer [20,21], and ovarian cancer [22] cells mainly by inhibiting proliferation, inducing apoptosis and inactivating NFkB activity. Ginger supplementation at $2 \mathrm{~g}$ daily for 28 days to 20 patients at high risk of colorectal cancer resulted in a reduced proliferation rate (reduced expression of Ki-67) but had less effect on apoptosis in the crypts of normal appearing colonic mucosa cells [23].

Gelam and Tualang honeys from Malaysia exhibit anti-cancer properties such as inhibition of cell proliferation and DNA damage, induction of apoptosis and cell cycle arrest of liver and colon cancer cells [24,25], human osteosarcoma cells (HOS) [26], breast cancer cells (MCF-7 and MDA-MB-231) and cervical cancer cells (HeLa) [27]. Gelam honey also exhibits antiinflammatory effects by significantly decreasing the production of pro-inflammatory cytokines such as NO, PGE2, TNF- $\alpha$, and IL- 6 in carrageenan-induced acute paw edema in rats [28]. The anti-inflammatory and anti-tumor properties of Gelam honey were suggested to be due to the high content of phenolic compounds such as gallic acid, chlorogenic acid, caffeic acid, $p$ - coumaric acid, ferulic acid, ellagic acid, quercetin, hesperetin and chrysin [24,28].

Our earlier study showed that the combination of ginger and Gelam honey enhances the chemotherapeutic effect of 5-fluorouracil against colon cancer line HTC116 [29]. However, the mechanisms involved are still unclear. In the present study, crude extracts of ginger and Gelam honey were used in combination to determine their potential synergistic chemopreventive effect against HT29 colorectal cancer cells, focusing on molecular mechanisms involving the Ras/ERK and PI3K/AKT pathways that may represent the early stage of colorectal cancer formation.

\section{Methods}

\section{Cell culture}

Human colorectal adenocarcinoma cell line HT29 was obtained from the American Type Culture Collection (ATCC, Rockville, MD, USA). HT29 cells were chosen because they are sensitive to treatment with chemotherapeutic drugs and maintain as a nonpolarized, undifferentiated multilayer. The cell line was maintained in a T-25 flask containing McCoy's 5A Medium Modified with Lglutamine (Gibco Life Technologies, Inc., Grand Island, NY, USA) and supplemented with $10 \%$ fetal calf serum (FCS), $100 \mathrm{U} / \mathrm{mL}$ penicillin-streptomycin (Gibco Life Technologies, Inc., Grand Island, NY, USA) and 100 U/ $\mathrm{mL}$ amphotericin B (PAA Laboratories $\mathrm{GmbH}$, Pasching, Austria) at $37^{\circ} \mathrm{C}$ in a humidified atmosphere of $5 \% \mathrm{CO}_{2}$. The cell line was maintained as a monolayer and split regularly before reaching $80-90 \%$ confluence.

\section{Source of ginger extract and Gelam honey}

The crude ginger extract was supplied by Dr. Noor Azian Murad of the Centre of Lipid Engineering and Applied Research (CLEAR), Universiti Teknologi Malaysia. Ginger extract was isolated by ultrasonic assisted extraction (UAE) using water at $20-2200 \mathrm{kHz}$ frequency for 10-120 minutes and temperature of 30$140^{\circ} \mathrm{C}$. The extract was filtered into a $20 \mathrm{ml}$ falcon tube and stored at $-80^{\circ} \mathrm{C}$. The frozen extract was freeze-dried to form a powder and stored at room temperature before use. Local fresh Malaysian monofloral Gelam honey was provided by the National Apiary, Department of Agriculture, Batu Pahat, Johor, Malaysia. The Gelam honey was packaged in plastic containers and sent to SINAGAMA, Malaysian Nuclear Agency for sterilization by gamma irradiation. The irradiation process was performed at $25 \mathrm{kGy}$ and the honey was subsequently stored at $4^{\circ} \mathrm{C}$ away from direct light for future use. The ginger and Gelam honey were diluted with complete culture medium at varying concentrations for the experiments. 


\section{Cell viability assay}

Cell viability was assessed by using MTS (3-(4,5-dimethylthiazol-2-yl)-5-(3-carboxymethoxyphenyl)-2-(4-sulphenyl)-2H-tetrazolium) (Promega, Madison, WI, USA). HT29 cells were plated in 96-well plates at a density of $2 \times 10^{4}$ cells per $100 \mu \mathrm{L}$ complete medium (McCoy $5 \mathrm{~A}$ Medium Modified) and incubated for 24 hours at $37^{\circ} \mathrm{C}$ in a $5 \% \mathrm{CO}_{2}$ incubator. After 24 hours of incubation, the culture medium was removed and replaced with $100 \mu \mathrm{L}$ of new complete medium for the control group, $100 \mu \mathrm{L}$ of ginger $(2-10 \mathrm{mg} / \mathrm{ml}), 100 \mu \mathrm{L}$ of Gelam honey (20$100 \mathrm{mg} / \mathrm{ml}$ ) or the combination of both ginger and Gelam honey at various concentrations to the appropriate wells. Three replicates were performed for each treatment. The plate was then wrapped in aluminum foil and subsequently re-incubated for another 24 hours. After the incubation period, the culture medium was discarded and replaced with MTS solution $(20 \mu \mathrm{L}$ MTS diluted in $100 \mu \mathrm{L}$ complete medium) in each well before being incubated again at $37^{\circ} \mathrm{C}, 5 \% \mathrm{CO}_{2}$ for another 2 hours. The resulting products were determined spectrophotometrically at an absorbance of $490 \mathrm{\eta m}$ using VERSAmax microplate reader (Molecular Devices, Sunnyvale, CA, USA). The results are expressed as a percentage for each treatment group relative to the control in the absence of ginger and Gelam honey.

\section{Treatment of HT29 cells with the combination of ginger and Gelam honey}

HT29 cells were incubated for 24 hours with a fixed concentration of 2,3 or $4 \mathrm{mg} / \mathrm{ml}$ of ginger and varying concentrations of Gelam honey $(1-70 \mathrm{mg} / \mathrm{mL})$. The combination concentrations that were used were lower than the $\mathrm{IC}_{50}$ of single treatment with ginger and Gelam honey. The data were then analyzed using the Chou and Talalay formula [30] for the calculation of the combination index, $\mathrm{CI}$ as follows:

$$
C I=(d A / D A)+(d B / D B)
$$

where $\mathrm{dA}=$ the $\mathrm{IC}_{50}$ of compound $\mathrm{A}$ in combination, $\mathrm{DA}=$ the $\mathrm{IC}_{50}$ of single compound $\mathrm{A}, \mathrm{dB}=\mathrm{IC}_{50}$ of compound $\mathrm{B}$ in combination, $\mathrm{DB}=$ the $\mathrm{IC}_{50}$ of single compound B. Additivity, $\mathrm{CI}=1$; antagonism, $\mathrm{CI}=>1$; synergism, $\mathrm{CI}=<1$.

\section{Cell death detection by ELISA assay}

The mechanism of cell death was quantitatively determined using the Cell Death Detection ELISA PLUS 96 kit (Roche Applied Science, Mannhein, Germany) according to the manufacturer's protocol. Briefly, $2 \times 10^{4}$ HT29 cells were seeded in 96-well plates and were incubated overnight at $37^{\circ} \mathrm{C}$ in a $5 \% \mathrm{CO}_{2}$ incubator. Following an overnight incubation period, the cells were treated with either ginger, Gelam honey or the combination for another 24 hours. The treated cells were lysed with $200 \mathrm{ml}$ of lysis buffer and incubated for 30 minutes at room temperature. The lysed solution $(20 \mu \mathrm{L})$ was placed in triplicate into wells of a streptavidin-coated microplate followed by the addition of $80 \mu \mathrm{L}$ of immunoreagent containing a mixture of anti-histone-biotin and anti-DNA-POD. The plate was covered with an adhesive foil cover and incubated for 2 hours at $25^{\circ} \mathrm{C}$ in a shaking incubator at $300 \mathrm{rpm}$. The unbound antibody was washed three times with $250-300 \mathrm{ml}$ incubation buffer. ABTS (2,2'-azinobis-3-ethyl-benzothiazoline-6sulfonic acid) solution $(100 \mu \mathrm{L})$ was added to each well and incubated on a plate shaker for 10-20 minutes. The amount of nucleosomes retained by the POD in the immunocomplex, corresponding to the extent of apoptosis, was quantitatively determined photometrically with ABTS solution as substrate using a microplate reader at a wavelength of $405 \mathrm{~nm}$ and reference wavelength of $490 \mathrm{~nm}$.

\section{Real-Time Polymerase Chain Reaction (RT-qPCR)}

A total of $1 \times 10^{6} \mathrm{HT} 29$ cells were plated in a $60 \mathrm{~mm}$ culture dish and incubated for 24 hours at $37^{\circ} \mathrm{C}$ in $5 \%$ $\mathrm{CO}_{2}$. The cells were then treated with different doses of ginger, Gelam honey or the combination of ginger and Gelam honey for 24 hours. The cells were harvested, cellular RNA was extracted using an RNeasy Mini kit (QIAGEN, Valencia, CA, USA) in an RNase-free environment according to the manufacturer's instructions, and it was subsequently purified by ethanol precipitation. RNA concentration and purity were determined based on measurement of the absorbance at $260 \mathrm{~nm}$ and $280 \mathrm{~nm}$. For each sample, approximately $200 \mathrm{ng}$ of RNA was used to synthesize cDNA. RNA was initially mixed with ultra-pure distilled water up to $16 \mu \mathrm{l}$ and mixed with $4 \mu \mathrm{l}$ of iScript $^{\mathrm{Tm}}$ Reverse Transcription Supermix (BIO-RAD, Hercules, CA, USA), which contains reverse transcriptase, RNase inhibitor, dNTPs, primer, $\mathrm{MgCl}_{2}$ and stabilizers. PCR-reaction primers were designed using the National Centre for Biotechnology Information (NCBI) website. The primer sequences that were used are shown in Table 1.

RT-qPCR was performed using SYBR-green detection (BIO-RAD, Hercules, CA, USA) in an iQ5 Real-time cycler machine (BIO-RAD, Hercules, CA, USA). The cycling conditions were as follows: initial denaturation at $95^{\circ} \mathrm{C}$ for $3 \mathrm{~min}$ and amplification for 40 cycles $\left(95^{\circ} \mathrm{C}\right.$ for $10 \mathrm{sec}$ for the denaturation, $56^{\circ} \mathrm{C}$ for $30 \mathrm{sec}$ for the annealing and extension). The quality of the PCR products was checked by $2 \%$ agarose gel electrophoresis. In all cases, single bands of the expected size were observed. The specificity of each PCR product was further assessed 
Table 1 Primer sequences for quantitative real-time RT-PCR

\begin{tabular}{lll}
\hline Gene & Forward primer (F) & Reverse primer (R) \\
\hline GADPH & TCCCTGAGCTGAACGGGAAG & GGAGGAGTGGTGTCGCTGT \\
Kras & TAGTTGGAGCTGGTGGCGTA & CCTCTTGACCTGCTGTGTCG \\
Erk & ACAGGCTGTCCCAAATGCT & CGAACTTGAATGGTGCTTCG \\
Akt & GTCGCCTGCCCTTCTACAAC & CACACGATACCGGCAAAGAA \\
Bcl-xl & GCATTGTGGCCTITTCTCC & GCTGCTGCATTGTTCCCATA \\
Caspase 9 & GAGGGAAGCCCAAGCTCTT & CACTGGGTTGGGCAAACTA \\
P65 & CCTGGGAATCCAGTGTGTGA & GCACTGTCACCTGGAAGCAG \\
lкBa & GAAGTGATCCGCCAGGTGAA & CTCACAGGCAAGGTGTAGGG \\
\hline
\end{tabular}

by melting curve analysis. The relative amount of gene expression normalized to the internal control GAPDH [31] was calculated according to the following formula:

Relative Expression Value (REV) $=2^{\text {(Ct GAPDH-Ct target gene) }}$

where $\mathrm{Ct}=$ the cycle number at threshold level.

\section{Statistical analysis}

All data were statistically analyzed using Statistical Package for Social Sciences (SPSS) software version 20. The normality of each test was assessed using the ShapiroWilk test. Normally distributed data were then tested with one-way ANOVA followed by Tukey's HSD test as a post-hoc test. For data values that were not normally distributed, they were analyzed using non-parameter tests (Kruskal-Wallis and Mann-Whitney). All data are presented as the mean \pm standard error (SEM), and $\mathrm{p}<$ 0.05 was considered statistically significant.

\section{Results}

Effects of treatment with ginger and Gelam honey on the viability HT29 cell line

Figure $1 \mathrm{~A}$ and $\mathrm{B}$ show the $\mathrm{IC}_{50}$ of ginger extract and Gelam honey to be $5.2 \mathrm{mg} / \mathrm{ml}$ and $80 \mathrm{mg} / \mathrm{ml}$, respectively.
The viability of HT29 cells did not show any changes when treated at low concentrations with ginger (2 and $4 \mathrm{mg} / \mathrm{ml}$ ) or Gelam honey (20, 40 and $60 \mathrm{mg} / \mathrm{ml})$. Whereas at high concentration, both ginger and Gelam honey decreased the viability of HT29 cells significantly $(\mathrm{p}<0.05)$ compared to untreated cells.

\section{Effects of combined treatment with ginger and Gelam honey on the viability HT29 cell line}

The combined treatment doses chosen for ginger (2, 3 and $4 \mathrm{mg} / \mathrm{ml}$ ) and Gelam honey (10 to $70 \mathrm{mg} / \mathrm{ml}$ ) were lower than the $\mathrm{IC}_{50}$ values of the individual treatments. A dose of $2 \mathrm{mg} / \mathrm{ml}$ of ginger needed a higher concentration of honey $(67 \mathrm{mg} / \mathrm{ml})$ to achieve the required $\mathrm{IC}_{50}$, whereas both 3 and $4 \mathrm{mg} / \mathrm{ml}$ of ginger required lower concentrations of Gelam honey $(27 \mathrm{mg} / \mathrm{ml}$ and $10 \mathrm{mg} / \mathrm{ml}$, respectively) to achieve the required $\mathrm{IC}_{50}$ (Figure 2). Table 2 shows that the combination index (CI) for $2 \mathrm{mg} / \mathrm{ml}$ of ginger with $67 \mathrm{mg} / \mathrm{ml}$ of Gelam honey is $1.21(\mathrm{CI}>1)$, which suggests an antagonistic effect. The combinations of 3 and $4 \mathrm{mg} / \mathrm{ml}$ of ginger with 27 and $10 \mathrm{mg} / \mathrm{ml}$ of Gelam honey showed CI values of 0.92 and 0.90 , respectively, indicating a synergistic effect between the two compounds.

\section{Effects of single and combined treatments with ginger \& Gelam Honey on apoptosis of HT29 cells}

As illustrated in Figure 3, treatment with ginger elicited a dose-dependent increase in DNA fragmentation that was higher compared to treatment with honey, indicating a higher rate of apoptosis. Interestingly, when $3 \mathrm{mg} / \mathrm{ml}$ of ginger was combined with $50 \mathrm{mg} / \mathrm{ml}$ of honey, a synergistic increase in the rate of apoptosis was seen compared to treatment with honey alone.

Effect of ginger \& Gelam honey alone and in combination on genes in the Ras/ERK \& PI3k/AKT pathways

Modulation of the gene expression of KRAS, ERK, AKT, $B c l-x L$, caspase 9, $p 65$ and $I \kappa B \alpha$ involved in the Ras/ERK

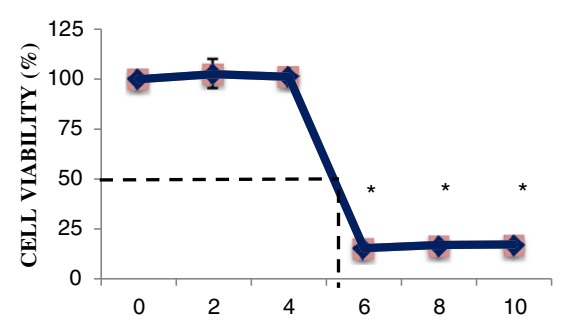

A CONCENTRATION OF GINGER $(\mathrm{mg} / \mathrm{ml})$

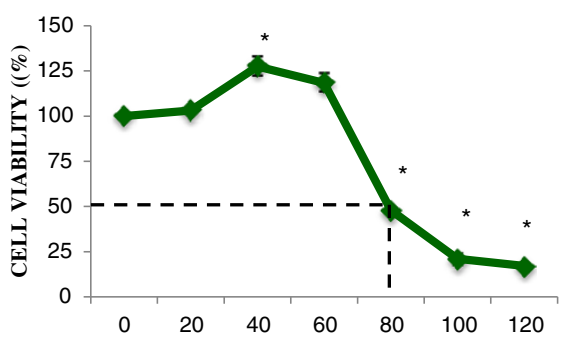

B CONCENTRATION OF GELAM HONEY $(\mathrm{mg} / \mathrm{ml})$

Figure 1 Effects of ginger and Gelam honey alone on viability of HT29 cells. Viability of HT29 cells with treatment of Ginger (A) and Gelam honey (B) was determined by MTS assay after 24 hour treatment with increasing concentrations of ginger or Gelam honey. Data are presented as the mean \pm SEM from three independent experiments. ${ }^{*}(p<0.05)$ significant compared to without treatment. 


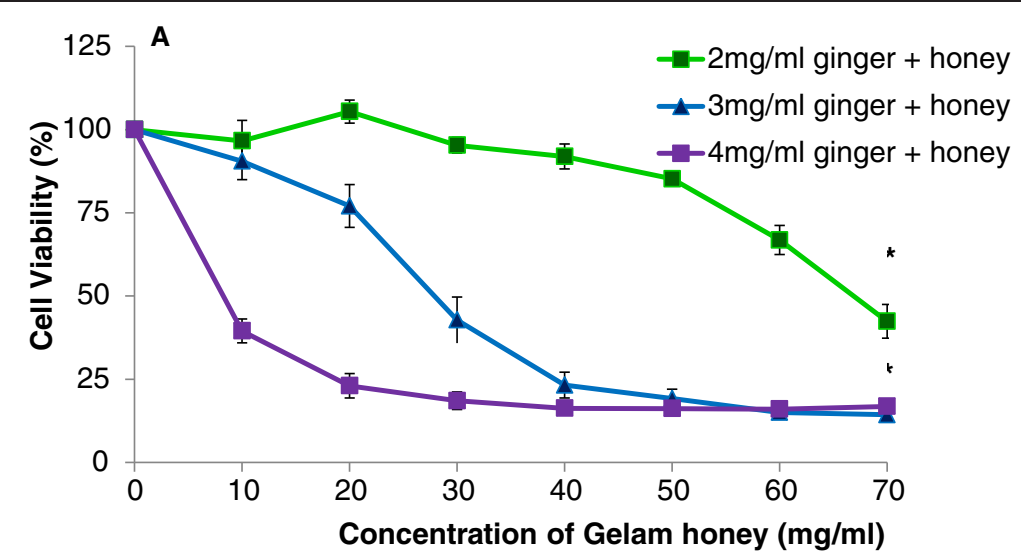

Figure 2 Effects of ginger and Gelam honey combined on viability of HT29 cells. Cell viability was determined by MTS assay after 24 hour treatment with increasing concentrations of ginger and Gelam honey combined. Data are presented as the mean \pm SEM from three independent experiments. ${ }^{*}(p<0.05)$ significant compared to without treatment.

and PI3K/AKT pathways was investigated with ginger and Gelam honey. The gene expression levels of KRAS, $E R K$ and $A K T$ involved in the Ras/ERK/PI3K/AKT pathways were high in control cells (Figure $4 \mathrm{~A}, \mathrm{~B}$, and $\mathrm{C}$ ). Treatment with ginger or Gelam honey alone resulted in the downregulation of the KRAS gene compared to control. However, a synergistic downregulation of KRAS was observed with combination treatment, especially at the dose of $3 \mathrm{mg} / \mathrm{ml}$ ginger in combination with either 30 or $50 \mathrm{mg} / \mathrm{ml}$ honey. As shown in Figure 4B, treatment with ginger alone downregulated expression of the ERK gene in a dose dependent manner, but combination of ginger with Gelam honey showed a greater effect on downregulating ERK gene expression compared to ginger or Gelam honey treatment alone. Treatment with either ginger or Gelam honey was found to downregulate $A K T$ gene expression independently of the dose (Figure $4 \mathrm{C}$ ). However, combination of both ginger and Gelam honey yielded higher downregulation of $A K T$ gene expression at a much lower concentration compared to either treatment alone. The expression of $\mathrm{Bcl}$ $x L$, an anti-apoptosis gene that was upregulated in the control group, was downregulated by either individual treatment, whereas combination treatment showed an

Table 2 The combination index $(\mathrm{Cl})$ for combined ginger and Gelam honey on HT29 cell line

\begin{tabular}{lll}
\hline Ginger $(\mathrm{mg} / \mathrm{ml})$ & $\begin{array}{l}\mathrm{IC}_{50} \text { Gelam } \\
\text { honey }(\mathrm{mg} / \mathrm{ml})\end{array}$ & $\begin{array}{l}\text { Combination } \\
\text { Index }(\mathrm{Cl})\end{array}$ \\
\hline $\mathbf{2}$ & 67 & 1.21 \\
$\mathbf{3}$ & 27 & 0.92 \\
$\mathbf{4}$ & 10 & 0.90 \\
\hline
\end{tabular}

Combination index, $\mathrm{Cl}$ was determined according to Chou and Talalay [30] as explained in the Methods section. Additivity, $\mathrm{Cl}=1$; antagonism, $\mathrm{Cl}=>1$; synergism, $\mathrm{Cl}=<1$. even greater effect (Figure 4D). Conversely, expression of the pro-apoptosis gene caspase 9 (Figure 4E), which was downregulated in the untreated control group, was upregulated in treatments with high concentrations of ginger or Gelam honey alone, and a synergistic upregulation of caspase 9 was observed with the combined treatment at a much lower dose. As seen in Figure 4F, the inflammatory gene $N F \kappa B(p 65)$, which is upregulated in cancer cells, was downregulated in treatments with ginger and Gelam honey alone or in combination, whereas the inhibitory gene $I \kappa B \alpha$ (Figure 4G), which is downregulated in cancer cell lines, was highly upregulated with the combination treatment.

\section{Discussion}

Chemoprevention, the use of natural dietary compounds to block, inhibit, and reverse the process of tumor formation, is a relatively new strategy to prevent cancer. Many studies have focused on natural products such as vegetables, fruits, spices, teas, herbs and phytochemical constituents such as flavonoids, carotenoids, alkaloids, and compounds containing nitrogen or organosulfur as potential chemopreventive agents [32]. Accumulating evidence indicates that the development and progression of many cancers, including colorectal cancer, is associated with deregulation of multiple signaling pathways that promote proliferation, inhibit apoptosis and induce metastasis [6]. The Ras and PI3K/ AKT pathways have been implicated in the tumorigenesis of colon cancer [6-8,33]. Dietary components such as ginger, garlic, soy, curcumin, chilies and green tea have been shown to reduce the incidence of many cancers [34].

A growing number of in vitro and in vivo studies have suggested that combinations of dietary phytochemicals 


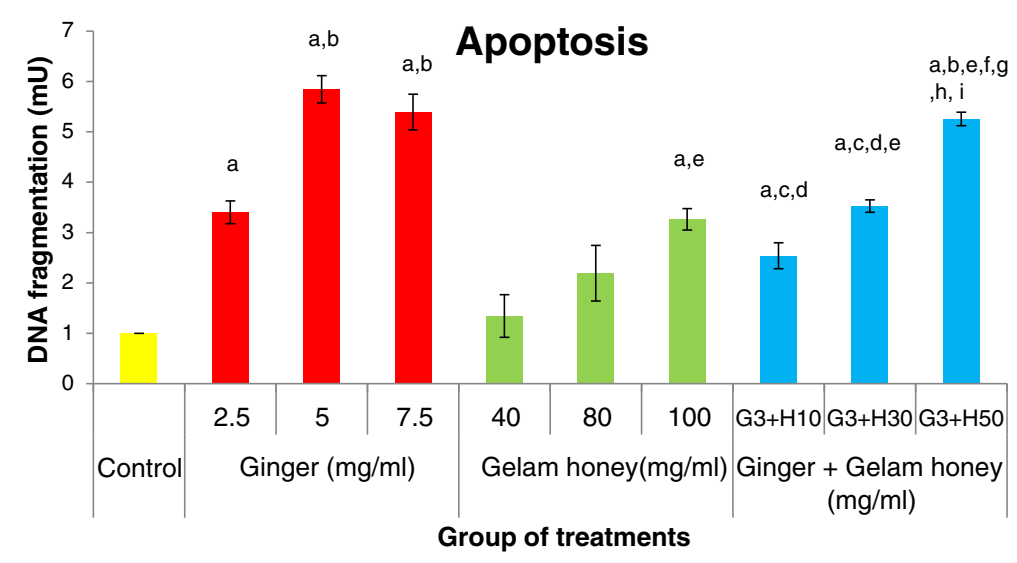

Figure 3 Effects of ginger and Gelam honey on apoptosis of HT29 cells. The apoptotic effects of single and combined treatments with ginger and Gelam honey were determined by Cell Death Detection ELISA after 24 hours. Data are presented as the mean \pm SEM from three independent experiments. ${ }^{a}(p<0.05)$ significant compared to control, ${ }^{b}(p<0.05)$ significant compared to $2.5 \mathrm{mg} / \mathrm{ml}$ of ginger, $^{c}(p<0.05)$ significant compared to $5.0 \mathrm{mg} / \mathrm{ml}$ of ginger, ${ }^{d}(p<0.05)$ significant compared to $7.5 \mathrm{mg} / \mathrm{ml}$ of ginger, $\mathrm{e}(\mathrm{p}<0.05)$ significant compared to $40 \mathrm{mg} / \mathrm{ml}$ of Gelam honey, ${ }^{f}(p<0.05)$ significant compared to $80 \mathrm{mg} / \mathrm{ml}$ of Gelam honey, ${ }^{9}(p<0.05)$ significant compared to $100 \mathrm{mg} / \mathrm{ml}$ of Gelam honey, ${ }^{h}(p<0.05)$ significant compared to combination of $3 \mathrm{mg} / \mathrm{ml}$ ginger and $10 \mathrm{mg} / \mathrm{ml}$ Gelam honey, ${ }^{i}(p<0.05)$ significant compared to combination of $3 \mathrm{mg} / \mathrm{ml}$ ginger and $30 \mathrm{mg} / \mathrm{ml}$ Gelam honey.

targeting multiple signaling pathways are far more effective at enhancing cytotoxic activity and inhibiting the growth of cancer cells $[8,9]$. In this study, the combination of $3 \mathrm{mg} / \mathrm{ml}$ of ginger and $27 \mathrm{mg} / \mathrm{ml}$ of Gelam honey was found to be the most effective dose to cause $50 \%$ death in HT29 colorectal cancer cells $(\mathrm{p}<0.05)$, in contrast to the individual compounds which needed higher concentrations. Isobologram analysis gave a combination index value $(\mathrm{CI})$ of 0.92 , indicating a synergistic effect between ginger and Gelam honey as antiproliferative agents. This dose was found to be equal to the effect of individual Gelam honey treatment at a very high concentration $(80 \mathrm{mg} / \mathrm{ml})$ at causing cell death. Similarly, Majumdar et al. [35] reported that the combination of curcumin and resveratrol was far more effective at inhibiting colon cancer cells (HCT116) compared to the individual compounds. Furthermore, the combination of two polyphenols, epigallocatechin-3gallate (EGCG) and curcumin, was found to be more effective than the individual compounds at inhibiting the growth of A549 lung cancer cells and human colorectal cancer cells [36,37].

We found that both individual and combination treatments with ginger and Gelam honey, polyphenol rich foods, induced early apoptosis in HT29 cells in a dosedependent manner with the combined treatment showing a higher rate of apoptosis. Additionally, ginger alone is far more effective at inducing apoptosis compared to Gelam honey. Abdullah et al. [17] showed that ginger oleoresin is capable of inducing early apoptosis and cell cycle arrest in HT29 cells, and Wen et al. [24] and Jubri et al. [25] showed that Gelam honey induces late apoptosis in HT29 and HepG2 cells, respectively. Nakamura et al. [38] reported that the combination of indole-3carbinol and genistein synergistically induces apoptosis in HT29 cells at a higher rate compared to the single treatments.

To our knowledge, no previous reports have elucidated the signaling pathway mechanisms involved when using the combination of Gelam honey and ginger against the proliferation of HT29 cells. KRAS/ERK and PI3K/AKT are two signaling pathways known to be interconnected and to play a role in colorectal carcinogenesis. The $K R A S, E R K$ and $A K T$ genes have been shown to be critical regulators of colon tumor growth through enhancing survival and reducing apoptosis [6].

We found that both individual and combined treatment with ginger and Gelam honey caused downregulation of KRAS gene expression, which was originally high in the untreated group, but a greater effect was seen in combination treatments using $3 \mathrm{mg} / \mathrm{ml}$ ginger with 30 or $50 \mathrm{mg} / \mathrm{ml}$ Gelam honey. Budan et al. [39] reported that a concoction of tea extracts known as "tea CoDTM", which contains a combination of Uncaria guianensis, cat's claw (Uncaria sp. U. tomentosa) and Palmer-trumpet tree (Tabebuia sp. T. avellanedae) extracts, inhibits KRAS gene expression in the liver, lungs and spleen of DMBA-treated mice.

The present study demonstrated that combining ginger and Gelam honey reduced the expression of the $E R K$ and $A K T$ genes in HT29 cells more effectively than treatment with the individual compounds. Down- 

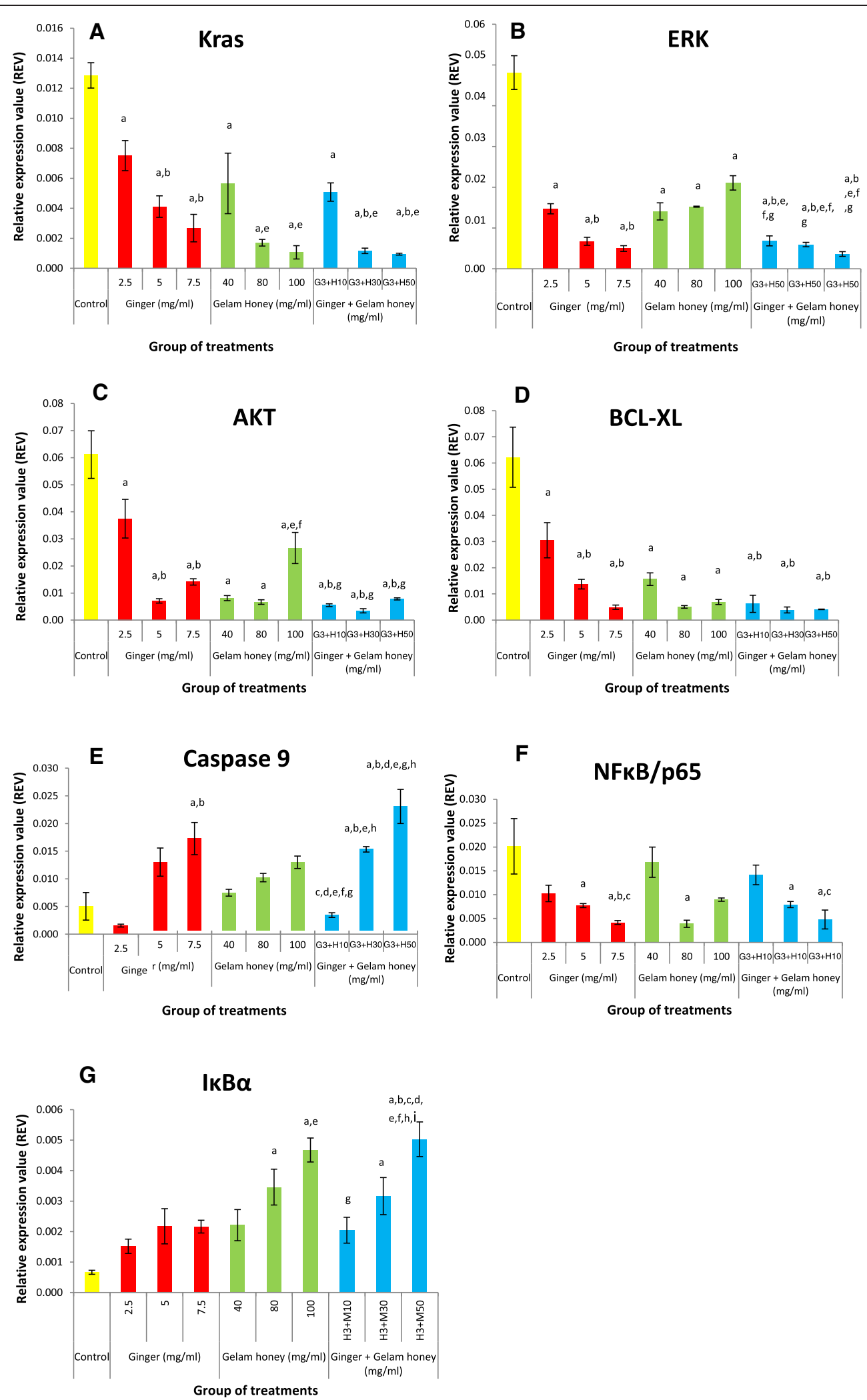

Figure 4 (See legend on next page.) 
(See figure on previous page.)

Figure 4 Effects of single and combined treatments with ginger \& Gelam honey on expression of Ras/ERK \& PI3K/AKT pathway genes in HT29 cells. RNA was isolated, reverse transcribed to CDNA, and then amplified by a real-time PCR detection system to measure mRNA levels of GAPDH, KRAS (A), ERK (B) AKT (C), BCl-xL (D), caspase 9 (E), NFKB/p65 (F), IKBa (G). Target genes were normalized to GAPDH. The data are presented as the mean \pm SEM from three independent experiments. ${ }^{a}(p<0.05)$ significant compared to control, ${ }^{b}(p<0.05)$ significant compared to $2.5 \mathrm{mg} / \mathrm{ml}$ of ginger, ${ }^{c}(p<0.05)$ significant compared to $5.0 \mathrm{mg} / \mathrm{ml}$ of ginger, ${ }^{d}(p<0.05)$ significant compared to $7.5 \mathrm{mg} / \mathrm{ml}$ of ginger, $\mathrm{e}(\mathrm{p}<0.05)$ significant compared to $40 \mathrm{mg} / \mathrm{ml}$ of Gelam honey, ${ }^{\mathrm{f}}(\mathrm{p}<0.05)$ significant compared to $80 \mathrm{mg} / \mathrm{ml}$ of Gelam honey, ${ }^{9}(\mathrm{p}<0.05)$ significant compared to $100 \mathrm{mg} / \mathrm{ml}$ of Gelam honey, ${ }^{h}(p<0.05)$ significant compared to combination of $3 \mathrm{mg} / \mathrm{ml}$ ginger and $10 \mathrm{mg} / \mathrm{ml} \mathrm{Gelam}$ honey, ${ }^{i}(p<0.05)$ significant compared to combination of $3 \mathrm{mg} / \mathrm{ml}$ ginger and $30 \mathrm{mg} / \mathrm{ml}$ Gelam honey.

regulation of the KRAS, ERK and $A K T$ genes, which are usually upregulated in proliferating cancer cells, was also observed by Xavier et al. [37] who reported that quercetin and luteolin, a type of flavonoid with high antioxidant activity, inhibits growth of HCT115 colon cancer cells by decreasing the gene expression of $K R A S, E R K$ and $A K T$. Ginger and Gelam honey contain high levels of flavonoids $[17,22,24,28]$, which may be responsible for blocking the activity of $K R A S, E R K$ and $A K T$ and their downstream components.

The PI3K/AKT pathway has been reported to play an important role in cell survival, inhibiting apoptosis through phosphorylation and inactivation of BAD, caspase-9 and forkhead transcription factor family members involved in the intrinsic apoptosis pathway. In addition, it will stimulate the expression of antiapoptotic proteins such as BCL-2 family, Bcl-xL and MCL-1 [6]. We demonstrated in this study upregulation of the anti-apoptotic gene $\mathrm{Bcl}-x \mathrm{l}$ in untreated HT29 cells, but it was downregulated further with combined treatment compared to individual treatment. Caspase 9 expression increased in a dose-dependent manner with ginger or Gelam honey treatment, but combined treatment showed a greater effect on inducing apoptosis. A similar study by Nakamura et al. [38] reported that combination of indole - 3 carbinol with genistein inhibits proliferation of HT29 cells through induction of apoptosis via inhibition of AKT protein phosphorylation and activation of caspase 9 protein, but no effect was seen from single treatment with either indole -3 carbinol or genistein. The combination of garsinol and curcumin induces apoptosis through activation of caspases 3 and 9 in the PaCa pancreatic cancer cell line [12].

We postulated that the bioactive compounds found in ginger and honey are responsible for inducing apoptosis through activation of apoptosis proteins (BAX, BAD and caspases 3,7, 8 and 9) and inactivation of anti-apoptotic proteins ( $\mathrm{BCL}-2$ and $\mathrm{Bcl}-\mathrm{xL}$ ) as reported by other researchers in $\mathrm{KB}$ oral cancer cells, Jurkat T-lymphoma cells, HepG2 cells, p53 hepatoma mutant cells, colon cancer and breast cancer cells [24,40-46].

Activation of nuclear factor kappa B (NFkB) occurs in many diseases including immune diseases, inflammation and cancer $[7,20,22,28]$. Gelam honey inhibits the production of inflammatory mediators such as NO, PGE2, TNF- $\alpha$, IL-6, iNOS and COX-2 in carrageenan-induced acute paw edema in rats $[28,47]$. We observed upregulation and downregulation of $N F \kappa B(p 65)$ and $I \kappa B \alpha$ in cancer cells, respectively, which was reversed by treatment with ginger and Gelam honey, with combined treatment showing greater modulation of these genes. Honey showed greater modulation of the genes compared to ginger, while the highest dose of combined treatment ( $3 \mathrm{mg} / \mathrm{ml}$ ginger $+50 \mathrm{mg} / \mathrm{ml}$ honey) protected the IкB $\alpha$ protein from destruction, thus preventing the translocation of p65 protein into the nucleus to activate transcription factors involved in cell proliferation and cell survival in HT29 colon cancer cells. Further studies to elucidate fully the mechanism of action of ginger and Gelam honey are required.

\section{Conclusion}

In conclusion, combined treatment with both ginger and Gelam honey is more effective than the individual treatments at inhibiting growth of HT29 colon cancer cells by inducing early apoptosis, modulating the expression of genes involved in the KRAS/ERK/ PI3K/AKT pathways and suppressing inflammation via the NFKB pathway. Thus, the combination of ginger and Gelam honey has potential as a chemopreventive strategy for inhibiting colorectal carcinogenesis by causing cell death.

\section{Competing interests}

The authors declare that they have no competing interests.

\section{Authors' contributions}

Study conception and design: SM and YAMY. Supplying ginger extract for the research: NAM. Acquisition, analysis and interpretation of data: AAT. Drafting of manuscript: AAT and NFAS. Critical revision: WZWN and YAMY. All authors read and approved the final manuscript.

\section{Acknowledgements}

This study was financially supported by Faculty of Medicine Universiti Kebangsaan Malaysia (FF-393-2012) and Universiti Kebangsaan Malaysia Research Grant (GUP-2012-016).

\section{Author details}

${ }^{1}$ Department of Biochemistry, Faculty of Medicine, Universiti Kebangsaan Malaysia, Jalan Yaacob Latif, Bandar Tun Razak, Cheras, 56000 Kuala Lumpur, Malaysia. ${ }^{2}$ Centre of Lipid Engineering and Applied Research (CLEAR), Universiti Teknologi Malaysia, Jalan Semarak, 50480 Kuala Lumpur, Malaysia. 
Received: 5 August 2014 Accepted: 3 March 2015

Published online: 01 April 2015

\section{References}

1. Jemal A, Bray F, Center MM, Ferlay J, Ward E, Forman D. Global cancer statistics. CA Cancer J Clin. 2011;61:69-90.

2. Omar ZA, Tamin NSI. National Cancer Registry Report, Malaysia Cancer Statistics - Data and Figure Report 2007. Ministry of Health Malaysia. 2011.

3. Grady WM, Carethers JM. Genomic and epigenetic instability in colorectal cancer pathogenesis. Gastroenterology. 2008;135:1079-99.

4. Pancione M, Remo A, Colantuoni V. Genetic and epigenetic events generate multiple pathways in colorectal cancer progression. Pathol Res Int. 2012;2012:11.

5. Downward J. Targeting RAS signalling pathways in cancer therapy. Nat Rev Cancer. 2003:3:11-22.

6. Chappell WH, Steelman LS, Long JM, Kempf RC, Abrams SL, Franklin RA, et al. Ras/Raf/MEK/ERK and PI3K/PTEN/Akt/mTOR inhibitors: rationale and importance to inhibiting these pathways in human health. Oncotarget. 2011:2:135.

7. Aggarwal BB, Takada Y, Oommen OV. From chemoprevention to chemotherapy: common targets and common goals. Expert Opin Investig Drugs. 2004;13:1327-38.

8. Sak K. Chemotherapy and dietary phytochemical agents. Chemother Res Pract. 2012;2012:11.

9. de Kok TM, van Breda SG, Manson MM. Mechanisms of combined action of different chemopreventive dietary compounds. Eur J Nutr. 2008;47:51-9.

10. George J, Singh M, Srivastava AK, Bhui K, Roy P, Chaturvedi PK, et al. Resveratrol and black tea polyphenol combination synergistically suppress mouse skin tumors growth by inhibition of activated MAPKs and p53. PLoS One. 2011;6:e23395.

11. Liu RH. Potential synergy of phytochemicals in cancer prevention: mechanism of action. J Nutr. 2004:134:3479S-85S.

12. Parasramka MA, Gupta SV. Synergistic effect of garcinol and curcumin on antiproliferative and apoptotic activity in pancreatic cancer cells. J Oncol. 2012;2012:8

13. Wang Z, Desmoulin S, Banerjee S, Kong D, Li Y, Deraniyagala RL, et al. Synergistic effects of multiple natural products in pancreatic cancer cells. Life Sci. 2008;83:293-300.

14. Ekowati $H$, Achmad A, Prasasti E, Wasito H, Sri K, Hidayati Z, et al. Zingiber officinale, Piper retrofractum and Combination Induced Apoptosis and p53 Expression in Myeloma and WiDr Cell Lines. HAYATI J Biosci. 2012;19:137.

15. Banerjee S, Mullick H, Banerjee J, GHOSH A. Zingiber officinale:'a natural gold'. Int J Pharmaceutical Bio-Sci. 2011;2:283-94.

16. Khater DS. The influence of ginger as a chemopreventive agent on proliferation and apoptosis in chemically induced oral carcinogenesis. Nat Sci. 2010;8:44-51.

17. Abdullah S, Abidin SAZ, Murad NA, Makpol S, Ngah WZW, Yusof YAM. Ginger extract (Zingiber officinale) triggers apoptosis and G0/G1 cells arrest in HCT 116 and HT 29 colon cancer cell lines. Afr J Biochem Res. 2010:4:134-42

18. Ishiguro K, Ando T, Maeda O, Ohmiya N, Niwa Y, Kadomatsu K, et al. Ginger ingredients reduce viability of gastric cancer cells via distinct mechanisms. Biochem Biophys Res Commun. 2007;362:218-23.

19. Nigam N, Bhui K, Prasad S, George J, Shukla Y. [6]-Gingerol induces reactive oxygen species regulated mitochondrial cell death pathway in human epidermoid carcinoma A431 cells. Chem Biol Interact. 2009;181:77-84.

20. Habib SHM, Makpol S, Hamid NAA, Das S, Ngah WZW, Yusof YAM. Ginger extract (Zingiber officinale) has anti-cancer and anti-inflammatory effects on ethionine-induced hepatoma rats. Clinics. 2008:63:807-13.

21. Yagihashi S, Miura Y, Yagasaki K. Inhibitory effect of gingerol on the proliferation and invasion of hepatoma cells in culture. Cytotechnology. 2008:57:129-36.

22. Rhode J, Fogoros S, Zick S, Wahl H, Griffith KA, Huang J, et al. Ginger inhibits cell growth and modulates angiogenic factors in ovarian cancer cells. BMC Complement Altern Med. 2007;7:44.

23. Citronberg J, Bostick R, Ahearn T, Turgeon DK, Ruffin MT, Djuric Z, et al. Effects of ginger supplementation on cell-cycle biomarkers in the normalappearing colonic mucosa of patients at increased risk for colorectal cancer: results from a pilot, randomized, and controlled trial. Cancer Prev Res (Phila). 2013;6:271-81.
24. Wen CTP, Hussein SZ, Abdullah S, Karim NA, Makpol S, Yusof YAM. Gelam and nenas honeys inhibit proliferation of HT 29 colon cancer cells by inducing DNA damage and apoptosis while suppressing inflammation. Asian Pac J Cancer Prev. 2012;13:1605-10.

25. Jubri Z, Narayanan NNN, Karim NA, Ngah WZW. Antiproliferative activity and apoptosis induction by gelam honey on liver cancer cell line. Int J Appl. 2012;2:4.

26. Ghashm AA, Othman NH, Khattak MN, Ismail NM, Saini R. Antiproliferative effect of Tualang honey on oral squamous cell carcinoma and osteosarcoma cell lines. BMC Complement Altern Med. 2010;10:49.

27. Fauzi AN, Norazmi MN, Yaacob NS. Tualang honey induces apoptosis and disrupts the mitochondrial membrane potential of human breast and cervical cancer cell lines. Food Chem Toxicol. 2011;49:871-8.

28. Hussein SZ, Mohd Yusoff K, Makpol S, Mohd Yusof YA. Gelam Honey Inhibits the Production of Proinflammatory, Mediators NO, PGE(2), TNF-a, and IL-6 in Carrageenan-Induced Acute Paw Edema in Rats. Evidence-Based Complement Alternat Med. 2012;2012:13.

29. Hakim L, Alias E, Makpol S, Ngah WZW, Morad NA, Yusof YAM. Gelam Honey and Ginger Potentiate the Anti Cancer Effect of 5-FU against HCT 116 Colorectal Cancer Cells. Asian Pacific journal of cancer prevention: APJCP. 2014;15:4651.

30. Chou T-C. Theoretical basis, experimental design, and computerized simulation of synergism and antagonism in drug combination studies. Pharmacol Rev. 2006;58:621-81.

31. Zainuddin A, Chua KH, Rahim NA, Makpol S. Effect of experimental treatment on GAPDH mRNA expression as a housekeeping gene in human diploid fibroblasts. BMC Mol Biol. 2010;11:59.

32. Surh Y-J. Cancer chemoprevention with dietary phytochemicals. Nat Rev Cancer. 2003:3:768-80.

33. Castellano E, Santos E. Functional Specificity of Ras Isoforms So Similar but So Different. Genes Cancer. 2011;2:216-31.

34. Dorai T, Aggarwal BB. Role of chemopreventive agents in cancer therapy. Cancer Lett. 2004;215:129-40.

35. Majumdar AP, Banerjee S, Nautiyal J, Patel BB, Patel V, Du J, et al. Curcumin synergizes with resveratrol to inhibit colon cancer. Nutr Cancer. 2009;61:544-53.

36. Zhou D-H, Wang X, Yang M, Shi X, Huang W, Feng Q. Combination of Low Concentration of (-)-Epigallocatechin Gallate (EGCG) and Curcumin Strongly Suppresses the Growth of Non-Small Cell Lung Cancer in Vitro and in Vivo through Causing Cell Cycle Arrest. Int J Mol Sci. 2013;14:12023-36.

37. Xavier CP, Lima CF, Preto A, Seruca R, Fernandes-Ferreira M, Pereira-Wilson C. Luteolin, quercetin and ursolic acid are potent inhibitors of proliferation and inducers of apoptosis in both KRAS and BRAF mutated human colorectal cancer cells. Cancer Lett. 2009;281:162-70.

38. Nakamura Y, Yogosawa S, Izutani Y, Watanabe H, Otsuji E, Sakai T. A combination of indol-3-carbinol and genistein synergistically induces apoptosis in human colon cancer HT-29 cells by inhibiting Akt phosphorylation and progression of autophagy. Mol Cancer. 2009;8:1476-4598.

39. Budán F, Szabó I, Varias T, Nowrasteh G, Dávid T, Gergely P, et al. Mixtures of Uncaria and Tabebuia extracts are potentially chemopreventive in CBA Ca mice: a long term experiment. Phytother Res. 2011;25:493-500.

40. Chen C-Y, Liu T-Z, Liu Y-W, Tseng W-C, Liu RH, Lu F-J, et al. 6-shogaol (alkanone from ginger) induces apoptotic cell death of human hepatoma p53 mutant Mahlavu subline via an oxidative stress-mediated caspasedependent mechanism. J Agric Food Chem. 2007;55:948-54.

41. Zhang G, Wang Y, Zhang Y, Wan X, Li J, Liu K, et al. Anti-cancer activities of tea epigallocatechin-3-gallate in breast cancer patients under radiotherapy. Curr Mol Med. 2012;12:163.

42. Harliansyah, Zurinah W, Anum M, Azian MN. Chemopreventive Efficacy of Ginger Extract (Zingiber officinale). Indonesian J Cancer Chemoprevent. 2010;1:2.

43. Keum Y-S, Kim J, Lee KH, Park KK, Surh Y-J, Lee JM, et al. Induction of apoptosis and caspase-3 activation by chemopreventive [6]-paradol and structurally related compounds in KB cells. Cancer Lett. 2002;177:41-7.

44. Miyoshi N, Nakamura Y, Ueda Y, Abe M, Ozawa Y, Uchida K, et al. Dietary ginger constituents, galanals $\mathrm{A}$ and $\mathrm{B}$, are potent apoptosis inducers in Human T lymphoma Jurkat cells. Cancer Lett. 2003;199:113-9.

45. Jaganathan S, Mandal M. Honey constituents and its apoptotic effect in colon cancer cells. J Apiproduct Apimed Sci. 2009;1:29-36. 
46. Yaacob NS, Nengsih A, Norazmi MN. Tualang honey promotes apoptotic cell death induced by tamoxifen in breast cancer cell lines. Evidence-Based Complement Altern Med. 2013;2013:9.

47. Kassim M, Achoui M, Mansor M, Yusoff KM. The inhibitory effects of Gelam honey and its extracts on nitric oxide and prostaglandin E2 in inflammatory tissues. Fitoterapia. 2010;81:1196-201.

Submit your next manuscript to BioMed Central and take full advantage of:

- Convenient online submission

- Thorough peer review

- No space constraints or color figure charges

- Immediate publication on acceptance

- Inclusion in PubMed, CAS, Scopus and Google Scholar

- Research which is freely available for redistribution 